

\section{DISCLAIMER}

This report was prepared as an account of work sponsored by an agency of the United States Government. Neither the United States Government nor any agency Thereof, nor any of their employees, makes any warranty, express or implied, or assumes any legal liability or responsibility for the accuracy, completeness, or usefulness of any information, apparatus, product, or process disclosed, or represents that its use would not infringe privately owned rights. Reference herein to any specific commercial product, process, or service by trade name, trademark, manufacturer, or otherwise does not necessarily constitute or imply its endorsement, recommendation, or favoring by the United States Government or any agency thereof. The views and opinions of authors expressed herein do not necessarily state or reflect those of the United States Government or any agency thereof. 


\section{DISCLAIMER}

Portions of this document may be illegible in electronic image products. Images are produced from the best available original document. 
This report was prepared as an account of work sponsored by an agency of the United States Government. Neither the United States Government nor any agency thereof, nor any of their employees, makes any warranty, express or implied, or assumes any legal liability or responsibility for the accuracy, completeness, or usefulness of any information, apparatus, product, or process disclosed, or represents that its use would not infringe privately owned rights. Reference herein to any specific commercial product, process, or service by trade name, trademark, manufacturer, or otherwise, does not necessarily constitute or imply its endorsement, recommendation, or favoring by the United States Government or any agency thereof. The views and opinions of authors expressed herein do not necessarily state or reflect those of the United States Government or any agency thereof.

\author{
Printed in the United States of America \\ Available from \\ National Technical Information Service \\ U.S. Department of Commerce \\ 5285 Port Royal Road \\ Springfield, Virginia 22161
}

NTIS Price Codes: Printed Copy A02; Microfiche A01 
GA-A16094

SUMMARY

UC-77

\title{
1170-MW(t) HTGR-PS/C PLANT APPLICATION STUDY REPORT: \\ GEISMAR, LOUISIANA REFINERY/CHEMICAL COMPLEX APPLICATION
}

\author{
by \\ A. T. McMAIN, JR., and \& D. STANLEY

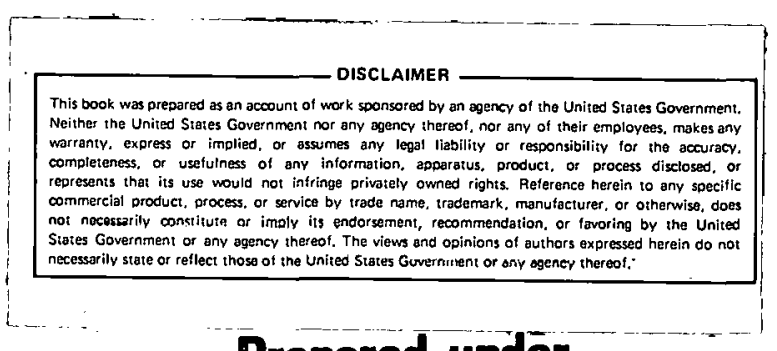 \\ Prepared under \\ Contract DE-AT03-76SF70046 \\ for the San Francisco Operations Office \\ Department of Energy
}

\section{GENERAL ATOMIC PROJECT 6600 DATE PUBLISHED: MAY 1981}


INTRODUCTION

Basic chemical, petrochemical, and petroleum refining processes are al1 very energy intensive. For this and other reasons, a large number of plants were built years ago on the U.S. Gulf Coast to use the area's inexpensive, plentiful natural gas to fuel process operations.

The recent dramatic changes in natural gas cost and availability and in government policy have caused process industries on the Gulf Coast and elsewhere to plan to ultimately convert to alternative process energy fuels, such as coal and uranium.

This report summarizes a study to apply an 1170-MW(t) high-temperature gas-cooled reactor - process steam/cogeneration (HTGR-PS/C) to an industrial complex at Geismar, Louisiana. This study compares the HIGR with coal and oil as process plant fuels. This study uses a previous broad energy alternative study by the Stone and Webster Corporation on refinery and chemical plant needs in the Gulf States Utilities service area (Ref. 1).

The HTGR-PS/C was developed by General Atomic (GA) specifically for industries which require both steam and electric energy. The GA 1170-MW( $t$ ) HTGR-PS/C design is particularly well. suited to industrial applications and is expected to have excellent cost benefits over other energy sources. Because the HTGR produces high-temperature, high-pressure steam at conditions identical to those from fossil-fired boilers, a fairly direct substitution can be made for existing large oil or gas-fired industrial boilers. This gives maximum flexibility in establishing cogeneration heat cycles to produce steam at process conditions. 
APPLICATION REQUIREMENTS

Steam Requi.rements

Table 1 gives the total projected steam requirements for consumers in the Geismar region.

\section{Electrical Requ1rements}

The present (1978) electrical requirements (in megawatts) for the consumers in the Geismar region are

$$
\frac{\text { User No. } 1}{150} \frac{\text { User No. } 2}{24} \frac{\text { User. No. 3 }}{96} \frac{\text { User No. 4 }}{78} \frac{\text { Tota1 }}{348}
$$

Projections indicate more than a $50 \%$ increase in electrical power consumption by 1985 .

PLANT DESIGN

The study selected steam distribution conditions from the cogeneration plants to the several industrial users at each site. Where possible, these conditions conform to extraction or exhaust conditions from the plant turbine generators. Further steam conditioning by throttling and/or desuperheating to meet required process conditions was assumed to be performed as necessary at each user plant. Steam flow rates were established to meet projected.user process steam demands.

Electric power was assumed to be purchased from or sold to Gulf States Utilities as necessary. The electric power cogenerated by the heat cycle used in the Stone and Webster study was insufficient to meet user plant requirements. However, this study developed a modified cycle with condensing turbine generators using three 1170-MW(t) HTGR-PS/C plants at full 
TABLE 1

STEAM REQUIREMENTS FOR GEISMAR AREA APPLICATION

\begin{tabular}{|c|c|c|c|c|c|c|}
\hline & \multicolumn{6}{|c|}{ Steam Requirements [kg/s $\left.\left(10^{6} 1 \mathrm{~b} / \mathrm{hr}\right)\right]$} \\
\hline & $\begin{array}{l}\text { User } \\
\text { No. } 1\end{array}$ & $\begin{array}{l}\text { User } \\
\text { No. } 2\end{array}$ & $\begin{array}{r}\text { User } \\
\text { No. } 3\end{array}$ & $\begin{array}{l}\text { User } \\
\text { No. } 3\end{array}$ & $\begin{array}{l}\text { User } \\
\text { No. } 4\end{array}$ & Total \\
\hline $\begin{array}{c}\text { Pressure } \\
{[\mathrm{MPa}(\mathrm{psig})]}\end{array}$ & $\begin{array}{l}4.41 \\
(640)\end{array}$ & $\begin{array}{l}4.48 \\
(650)\end{array}$ & $\begin{array}{l}4.41 \\
(640)\end{array}$ & $\begin{array}{l}6.55 \\
(950)\end{array}$ & $\begin{array}{l}1.72 \\
(250)\end{array}$ & \\
\hline $\begin{array}{c}\text { Temperature } \\
{\left[{ }^{\circ} \mathrm{C}\left({ }^{\circ} \mathrm{F}\right)\right]}\end{array}$ & $\begin{array}{l}393 \\
(740)\end{array}$ & $\begin{array}{l}393 \\
(740)\end{array}$ & $\begin{array}{l}393 \\
(740)\end{array}$ & $\begin{array}{l}393 \\
(850)\end{array}$ & NA & \\
\hline 1981 & $\begin{array}{l}222 \\
(1.76)\end{array}$ & $\begin{array}{l}95 \\
(0.75)\end{array}$ & $\begin{array}{l}113 \\
(0.90)\end{array}$ & $\begin{array}{l}47 \\
(0.37)(a)\end{array}$ & $\begin{array}{l}45 \\
(0.36)\end{array}$ & $\begin{array}{l}522 \\
(4.14)\end{array}$ \\
\hline $\begin{array}{l}1982 \\
:\end{array}$ & $\begin{array}{l}256 \\
(2.035)\end{array}$ & $\begin{array}{l}97 \\
(0.77)\end{array}$ & $\begin{array}{l}120 \\
(0.95)\end{array}$ & $\begin{array}{l}47 \\
(0.37)\end{array}$ & $\begin{array}{l}47 \\
(0.37)\end{array}$ & $\begin{array}{l}566 \\
(4.495)\end{array}$ \\
\hline 1983 & $\begin{array}{l}280 \\
(2.22)\end{array}$ & $\begin{array}{l}98 \\
(0.775)\end{array}$ & $\begin{array}{l}132 \\
(1.05)\end{array}$ & $\begin{array}{l}47 \\
(0.37)\end{array}$ & $\begin{array}{l}54 \\
(0.43)\end{array}$ & $\begin{array}{l}611 \\
(4.85)\end{array}$ \\
\hline 1984 & $\begin{array}{l}280 \\
(2.22)\end{array}$ & $\begin{array}{l}126 \\
(1.0)\end{array}$ & $\begin{array}{l}145 \\
(1.15)\end{array}$ & $\begin{array}{l}47 \\
(0.37)\end{array}$ & $\begin{array}{l}55 \\
(0.44)\end{array}$ & $\begin{array}{l}653 \\
(5.18)\end{array}$ \\
\hline 1985 & $\begin{array}{l}292 \\
(2.32)\end{array}$ & $\begin{array}{l}189 \\
(1.5)\end{array}$ & $\begin{array}{l}151 \\
(1.2)\end{array}$ & $\begin{array}{l}47 \\
(0.37)\end{array}$ & $\begin{array}{l}57 \\
(0.45)\end{array}$ & $\begin{array}{l}736 \\
(5.84)\end{array}$ \\
\hline 1986 & $\begin{array}{l}292 \\
(2.32)\end{array}$ & $\begin{array}{l}202 \\
(1.6)\end{array}$ & $\begin{array}{l}157 \\
(1.25)\end{array}$ & $\begin{array}{l}47 \\
(0.37)\end{array}$ & $\begin{array}{l}58 \\
(0.46)\end{array}$ & $\begin{array}{l}756 \\
(6.0)\end{array}$ \\
\hline 1987 & $\begin{array}{l}296 \\
(2.35)\end{array}$ & $\begin{array}{l}214 \\
(1.7)\end{array}$ & $\begin{array}{l}164 \\
(1.3)\end{array}$ & $\begin{array}{l}47 \\
(0.37)\end{array}$ & $\begin{array}{l}59 \\
(0.47)\end{array}$ & $\begin{array}{l}780 \\
(6.19)\end{array}$ \\
\hline 1988 & $\begin{array}{l}300 \\
(2.38)\end{array}$ & $\begin{array}{l}227 \\
(1.8)\end{array}$ & $\begin{array}{l}170 \\
(1.35)\end{array}$ & $\begin{array}{l}47 \\
(0.37)\end{array}$ & $\begin{array}{l}60 \\
(0.48)\end{array}$ & $\begin{array}{l}804 \\
(6 \cdot 38)\end{array}$ \\
\hline 1989 & $\begin{array}{l}307 \\
(2.44)\end{array}$ & $\begin{array}{l}239 \\
(1.9)\end{array}$ & $\begin{array}{l}183 \\
(1.45)\end{array}$ & $\begin{array}{l}47 \\
(0.37)\end{array}$ & $\begin{array}{l}62 \\
(0.49)\end{array}$ & $\begin{array}{l}838 \\
(6.65)\end{array}$ \\
\hline 1990 & $\begin{array}{l}315 \\
(2.5)\end{array}$ & $\begin{array}{l}252 \\
(2.0)\end{array}$ & $\begin{array}{l}195 \\
(1.55)\end{array}$ & $\begin{array}{l}47 \\
(0.37)\end{array}$ & $\begin{array}{l}63 \\
(0.5)\end{array}$ & $\begin{array}{l}872 \\
(6.92)\end{array}$ \\
\hline
\end{tabular}

(a) Projected steam usage not available; initial demand held constant. 
capacity to cover user needs and to produce surplus electric power for sale to the utility. Figure 1 shows the heat cycle.

Steam is distributed to the user plants at $6.69 \mathrm{MPa} / 408^{\circ} \mathrm{C}(970$ psia/ $\left.767^{\circ} \mathrm{F}\right), 4.55 \mathrm{MPa} / 366^{\circ} \mathrm{C}\left(660 \mathrm{psia} / 690^{\circ} \mathrm{F}\right.$ ), and $2.0 \mathrm{MPa} / 265^{\circ} \mathrm{C}$ (290 psia/ $\left.509^{\circ} \mathrm{F}\right)$. The plant produces $2214 \mathrm{MW}\left(7757 \times 10^{6} \mathrm{Btu} / \mathrm{hr}\right.$ ) of steam power and $702 \mathrm{MW}(\mathrm{e})$. Current consumption by the user plants is $348 \mathrm{MW}(\mathrm{e})$, leaving 354 MW(e) of surplus for sale to the utility or for future increases in the user plant consumption.

ECONOMIC ANALYSIS

The revenue requirement method was selected to evaluate alternative projects. This technique is appropriate for evaluating long-lived coal and nuclear cogeneration power plant projects. It determines the revenue needed by the firm as compensation for all fixed and variable expenditures. Hence, the revenue requirements of the firm equal. the consumer cost for the process steam cogenerated.

Table 2 compares estimated energy costs for the 1170-MW(t) HTGR-PS/C versus the comparable coal-fired PS/C plant and existing oil-fired plant for a refinery/chemical complex. It shows a clear advantage of the HTGR over both the coal-fired and oil-fired plants.

This analysis is based on economic assumptions used to evaluate utility cogeneration projects in progress for the Department of Energy (DOE) by GA in coordination with Gas Cooled Reactor Associates (GCRA). Table 3 gives the principal assumptions of the economic analysis, a key one being the $18 \%$ fixed charge rate for capital use/recovery. Such a rate may be higher if Industrial ownership ground rules are applied. Therefore, the economics should be determined using the economic ground rules appropriate for the specific application. Industrial user input is being developed regarding possible alternative economic ground rules. 


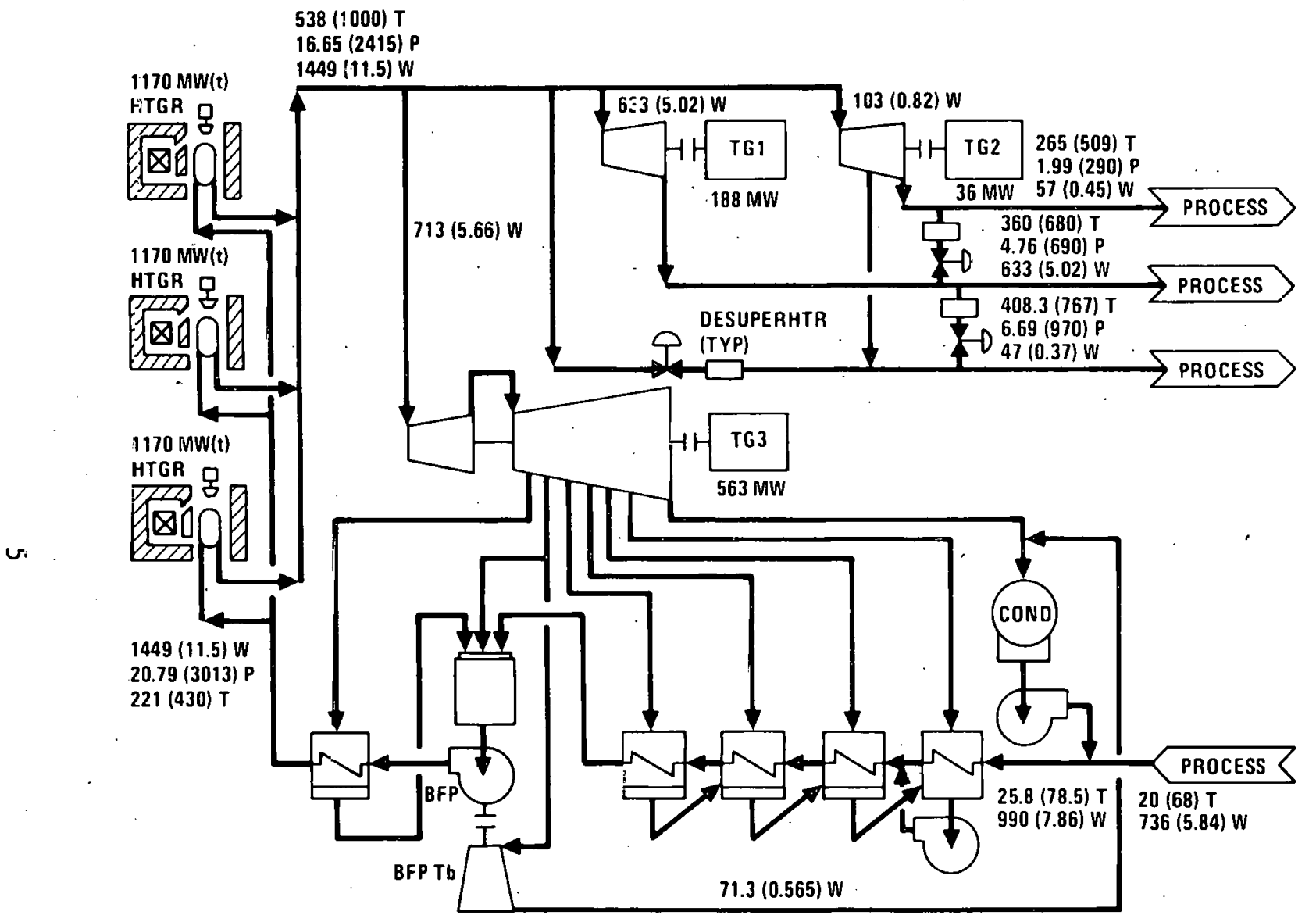

\begin{tabular}{|l|r|r|}
\hline $\begin{array}{c}\text { ALLOCATION OF REACTOR } \\
\text { POWER OUTPUT }\end{array}$ & MW & $\%$ \\
\hline PROCESS USES & & \\
ELECTRIC POWER & 348.0 & 9.9 \\
STEAM POWER TO PROCESS & 2214.2 & 63.1 \\
SUBTOTAL & 2562.2 & 73.0 \\
OTHER USES & & \\
ELECTRIC POWER & 375.3 & 10.7 \\
LOSSES & & \\
CONDENSER & 532.5 & 15.2 \\
OTHER & 40.0 & 1.1 \\
\multicolumn{2}{|c}{} & \\
TOTAL REACTOR POWER OUTPUT & 3510 & 100 \\
\hline
\end{tabular}

\section{LEGEND}

$W=F L O W K G / S\left(10^{6} \mathrm{LB} / \mathrm{HR}\right)$

$P$ = PRESSURE MPa (PSIA)

$T=$ TEMPERATURE ${ }^{\circ} \mathrm{C}\left({ }^{\circ} \mathrm{F}\right)$

Fig. 1. Cycle diagram for an 1170-MW(t) HTGR-PS/C plant for Gelsmar, Louisiana, petrochemical complex application (with condensing cycle) 
TABLE 2

ECONOMIC ANALYSIS OF HTGR-PS/C AND

ALTERNATIVE PLANTS FOR GEISMAR AREA APPLICATION

\begin{tabular}{|c|c|c|c|}
\hline & HTGR-PS / C & $\begin{array}{l}\text { Coal Without } \\
\text { Condensing }\end{array}$ & $\begin{array}{l}\text { Existing } \\
\text { No. } 2 \text { oil }\end{array}$ \\
\hline Heat input to cycle (MW) & 3510.0 & 2631.0 & 2214.6 \\
\hline Heat output in process steam (MW) & 2214.2 & 2214.6 & 2214.6 \\
\hline $\begin{array}{l}\text { Net electrical power output (MW) } \\
\text { Capital Costs }\left(\$ \times 10^{6}\right)\end{array}$ & 723.3 & 352.2 & -- \\
\hline Base capital cost $(1 / 80 \$)$ & 1654 & 825 & -- \\
\hline Escalation through construction & 1650 & 932 & -- \\
\hline Interest during construction & 1037 & 349 & -- \\
\hline Total capital cost (1/95 \$) & 4341 & 2106 & -- \\
\hline Annual Costs $\left(\$ \times 10^{6} /\right.$ year $)(a)$ & & & \\
\hline Fixed charges & 781 & 379 & -- \\
\hline Fuel costs & 242 & 640 & 2771 \\
\hline O\&M costs & 189 & 148 & 38 \\
\hline Credit for electric power & $(751)$ & $(366)$ & -- \\
\hline Total annual costs & 461 & 801 & 2809 \\
\hline $\begin{array}{l}\text { Process Steam Cost } \\
{[\mathrm{mills} / \mathrm{kW}(\mathrm{t})-\mathrm{hr}(\$ / \mathrm{MMBL})]}\end{array}$ & $34.0(9.96)$ & $59.0(17.30)$ & $206.7(60.61)^{-}$ \\
\hline $\begin{array}{l}\text { Ratio of Energy Cost to Cost } \\
\text { with HTGR-PS/C }\end{array}$ & & 1.7 & 6.1 \\
\hline
\end{tabular}

(a) $1 / 95$ \$ levelized over a 30-year period. 
TABLE 3

ECONOMIC ANALYSIS ASSUMPTIONS

Commercial operation of all plants: $1 / 95$

Capacity factor:

$70 \%$

Levelizing period:

30 years

Electric power credit:

$22 \mathrm{mills} / \mathrm{kW}-\mathrm{hr}(80 \mathrm{\$})$

Discount rate:

$10 \% /$ year

Fixed charge rate:

$18 \% /$ year

Interest during construction:

$10 \% /$ year (simple interest)

Coal cost escalation:

$8 \% /$ year

Fuel oil escalation:

$9 \% /$ year

All other escalation:

$6 \% /$ year

Construction period:

6 years for all plants

(2 years for No. 6 oilfired plants)

$\mathrm{U}_{3} \mathrm{O}_{8}$ (yellowcake) cost:

$\$ 121 / \mathrm{kg}(\$ 55 / 1 \mathrm{~b})$ in 1990 , rising to $\$ 264 / \mathrm{kg}$ ( $\$ 120 /$ 1b) in 2030

Separative work unit (SWU) cost:

$\$ 100 / \mathrm{kg}-\mathrm{SWU}(80 \$)$

Tails assay:

$0.2 \%$

Coal cost:

$4.64 \mathrm{mi} 11 \mathrm{~s} / \mathrm{kW}-\mathrm{hr}(\$ 1.36 /$ MMBtu) (80 \$)

No. 2 oil cost:

$18.2 \mathrm{mills} / \mathrm{kW}-\mathrm{hr}(\$ 5.33 /$ MMBtu) (80 \$)

No. 6 oil cost:

$13.5 \mathrm{mills} / \mathrm{kW}-\mathrm{hr}(\$ 3.95 /$ MMBtu) (80 \$)

HTGR-PS/C fuel cycle cost (includes recycle):

$11.23 \mathrm{mills} / \mathrm{kW}-\mathrm{hr}(\$ 3.29 /$ MMBtu) (1/95 \$ levelized over 30 years) 
Ultimately, the economic analysis method will be determined by the nuclear cogeneration plant ownership:

1. Industrial ownership with connection to the utility grid for backup electric power and sale of excess power (per recent Federal Energy Regulatory Commission rulings regarding a more favorable arrangement for industry).

2. Utility ownership with both steam and cogenerated electric power sold to nearby industry.

3. Consortia ownership and sale of energy to industry and local utilities.

The analysis compares the cost of process steam produced by the HTGR-PS/C with that produced by a coal-fired cogenerating plant and with the cost of burning No. 2 oil in existing equipment. It includes a credit for the electric power produced by the HTGR and coal-fired cogenerating plants. The analysis indicates a clear advantage for the HTGR over the coal and oil alternatives.

\section{REFERENCE}

1. "Cogeneration Feasibility Study in the Gulf States Utilities Service Area," Stone and Webster Corporation Report No. 12977, July 1979. 
GENERAL ATOM

GENERAL ATOMIC COMPANY

P. O. BOX 81608

SAN DIEGO, CALIFORNIA 92138 